\title{
Objectivity versus doctrine
}

SIR - It has been fashionable for scholars on the periphery of science to attack the idea that science can be objective and value-free. This view stems from confusion between different meanings of the word "science" as a highly subjective activity, a methodology that maximizes objectivity and the resulting body of knowledge. Although we have become more aware that unconscious bias is often hard to avoid, the goal of objectivity remains the foundation on which the success of science rests. No less than in Galileo's day, the deliberate introduction of ideological preconceptions into the scientific process undermines its integrity.

I was therefore dismayed that Sir Peter Medawar reviewed Not in Our Genes, by Lewontin, Rose, and Kamin, with enthusiasm (Nature 19 July, p. 255). Moreover, he even quoted approvingly part of the authors' frank statement of political purpose: "We share a commitment to the prospect of the creation of a more socially just - a socialist society. And we recognize that a critical science is an integral part of the struggle to create that society, just as we also believe that the social function of much of today's science is to hinder the creation of that society by acting to preserve the interests of the dominant class, gender, and race." Unfortunately, in admiring the goal of a just society, Medawar overlooks the possibility that the authors' commitment to Marxist doctrine would conflict with their commitment to objectivity.

In fact, the authors skilfully distort the views of scientists interested in human behavioural genetics, intelligence testing and sociobiology, condemning research in these areas as worthless rather than as necessarily limited in precision. Indeed, almost no biomedical research could meet their perfectionist standards. Moreover, they project upon their victims a political motivation equal in intensity, but opposite in direction, to their own. They even condemn Kety's classic demonstration of a major role of heredity in schizophrenia, ignoring the fact that genetic studies on this disease are likely to lead, through the reductionist molecular genetics that they decry, to specific chemical therapy.

Historically, this book must be regarded as part of the long campaign of a group from the radical left, called Science for the People, to outlaw the study of human behavioural genetics. While most of the book repeats this group's earlier arguments, there is one major shift. After many years of trying, with little success, to convince the world that genes have little to do with individual differences in behaviour or in potential, Lewontin et al. now deny any such naive cultural determinism and adopt the position long held by their opponents: intelligence is the product of gene-environment interactions. But their turnabout seems to be more a matter of strategy than of convinction: note the title of the book, and the statement that J.B.S Haldane and H.J. Muller "argued (along lines that we would not) that important aspects of human behavior were influenced by genes" (p. 73). Moreover, instead of gracefully seeking an end to the sterile polemics, they claim the high middle ground of interactionism for themselves, and they cast down their opponents with the epithet "biological determinist" repeated (in a familiar political tactic) on virtually every page.

The authors are unusual not only in the righteousness but also in the manners that they bring to scientific controversy. For example, after quoting Louis Agassiz's assertion (in the nineteenth century) that the human sciences can in principle be freed of politics and religion, they add that "The sentiment was echoed in 1975 by yet another Harvard professor and biological determinist, Bernard Davis, who assures us that 'neither religious nor political fervor can command the laws of nature"'". Then follows another quotation from Agassiz: "the brain of the negro is that of the imperfect brain of a seven-month infant in the womb of the white".

As a reviewer has noted, this slur, passing three authors and an editor, says much about the intent of the book (see M. Konner, Natural History, August 1984, p. 66).

Why does such doctrinaire and ambiguous rhetoric appeal to many thoughtful people, as it has to Medawar? Obvious reasons include the past misuse of genetic theories to support racism, fear that genetic studies of behavioural traits might reveal differences between races and the belief that it is racist even to entertain that possibility. But this belief, however well intentioned, is profoundly illogical: racism is the willingness to have race, rather than individual qualities, determine a person's social treatment. Moreover, modern genetics has made a major contribution to the struggle to overcome this evil. For the intellectual justification of racism has been the ancient assumption that the differences between races are typological - that all the members of one group differ from all the members of another. But in contrast to the naive support of this view by certain geneticists in the past, modern population genetics has utterly destroyed its typological foundation. We now know that the genetic differences between races (except for some physical traits subject to climatic selection) are statistical and overlapping, and so one cannot infer an individual's potential from his race.

Future advances in understanding human diversity could also help us to reach humanitarian goals, by improving our efforts to develop individual potentials. To be sure, since knowledge of genetic differences, like almost any scientific knowledge, could be used for ill as well as for good, it is understandable that some people focus on the immediate danger. But the shift of genetics from typological to populational thinking encourages confidence that its further advances can have a constructive social impact.

It is sad to see one with Medawar's eminence, and with his credentials as a writer on the philosophy (and on the manners) of science, lending credibility to this book. He does criticize its attack on reductionists, because he finds that they simply do not exist as described. But he does not question the existence of biological determinists, even though they are equally imaginary among modern biologists. He also approves what he terms the "right-thinking" quality of the book. But "right-thinking" (or orthodoxy) is a dangerous concept in matters involving science. If it refers only to the general goal of a just society, or to Medawar's stated belief that the world is in need of change, fine - but if it encompasses or condones political bias in the evaluation of science, it presents a grave challenge.

The extreme positions and the political propaganda presented in Not in Our Genes are unlikely to influence the views of many scientists close to the field. Nevertheless, the book may convince lay readers, and it will surely have a distorting influence on the public image of science.

Bacterial Physiology Unit,

BERNARD D. DAVIS

Harvard Medical School,

Boston, Massachussetts 02115, USA

\section{Genes-on}

SIR - We now have quite a large number of types of gene. It might be sensible to suggest they are all named in the same way, so that they can be instantly recognized, as enzymes are with their "ase". Maximum simplicity and clarity may be achieved if they all ended with "on", with enough on the front end to indicate their function or status. We have already: recon, muton, replicon, codon, cistron, operon, transposon, regulon, exon, intron operon. There must be others I have not thought of.

Recently a new gene with a widely conserved sequence which may control development in a wide range of segmented animals has been announced, how about "onton"? This would go well with a single oncogene being called an oncon.

Other conversions could be: plasmogene into cyton for cytoplasmic genes; palaeogene into palon; neogene into neogon; regulator into represson (distinct from regulon which means something else).

Perhaps a modern geneticist should define all these terms as proper units, so that we may all express ourselves with precision.

J.R.LLOYD

Westcott House, Sherborne,

Dorset DT9 $3 H F, U K$ 